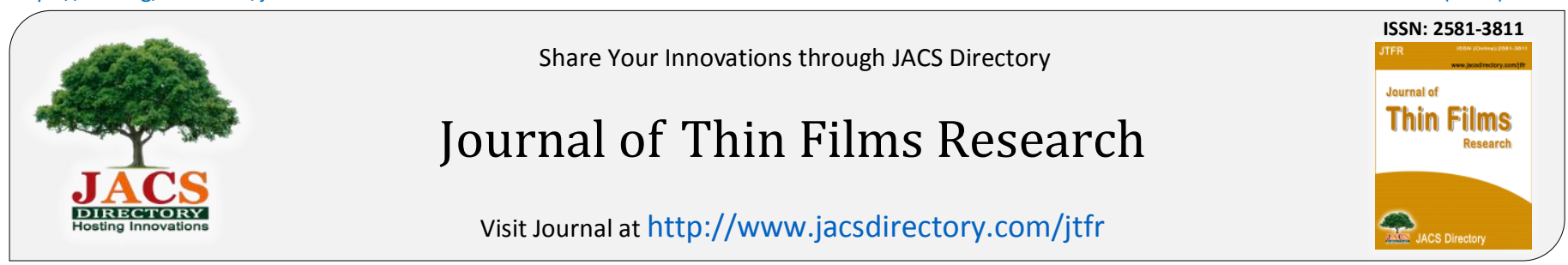

\title{
Optical Properties of Copper Aluminium Diselenide Thin Films under the Influence of Ammonium Solution as $\mathrm{pH}$ Adjuster
}

\author{
S.C. Ezike \\ Department of Physics, Modibbo Adama University of Technology, Yola, Adamawa State, Nigeria
}

\section{ARTICLE DETAILS}

\section{Article history:}

Received 01 July 2017

Accepted 09 July 2017

Available online 21 July 2017

\section{Keywords:}

Thin Films

Optical Properties

Copper Aluminum Diselenide

Ammonium Solution

\begin{abstract}
A B S T R A C T
Due expensive nature of silicon solar cells with indirect energy band gap, low-cost fabricated chalcogenide thin films are in focus. Copper Aluminium diselenide ( $\mathrm{CuAlSe}$ ) compound thin films are prepared by chemical bath deposition (CBD) technique. The films were deposited onto microscope glass slide $(7.5 \mathrm{~cm} \times 2.5 \mathrm{~cm} \times 0.1 \mathrm{~cm})$ in which influence of ammonium solution as $\mathrm{pH}$ adjuster is studied. The optical properties of deposited films were studied using UV-Vis spectrophotometer and results showed that the films thicknesses decrease as the volume ammonium solution increase which resulted in hindering films deposition an as well affected the energy band gaps ( $2.3 \mathrm{eV}$ to $3.0 \mathrm{eV})$ of the deposited films as $\mathrm{pH}$ values decrease. The $\mathrm{pH}$ played important role during the deposition process by affecting the optical properties of the films. This material is good candidate for optoelectronic properties by having moderate transmission in visible region of the spectrum and good UV filter since it absorbs higher in ultraviolet region.
\end{abstract}

\section{Introduction}

Copper indium diselenide $\left(\mathrm{CuInSe}_{2}\right)$ is the most widely known ternary semiconductor chalcopyrites compound thin films use as absorber in solar cells. Also other semiconductors of the same family like copper aluminium diselenide $\left(\mathrm{CuAlSe}_{2}\right)$ with wide band gap of $2.6 \mathrm{eV}$ [1] have attracted attention of researchers due its potential application in photovoltaic or detector devices [2,3]. Some studies of $\mathrm{Cu}(\mathrm{In}, \mathrm{Al}) \mathrm{Se}_{2}$ (CIAS), $\mathrm{CuGaSe}_{2}$ (CGS) and $\mathrm{Cu}(\mathrm{In}, \mathrm{Ga}) \mathrm{Se}_{2}$ (CIGS) thin films on transparent coated oxide (TCO) substrates obtained great results with efficiencies around 15\% [4-7]. Several methods of deposition of $\mathrm{CuAlSe}{ }_{2}$ thin films [8-21]. CBD method is preferred for its simplicity, inexpensive and capability to achieve large surface area coatings [16]. Generally, in a CBD process, ammonia $\left(\mathrm{NH}_{3}\right)$ solution is used as a complexing agent to bind the metallic ions so as to minimize the precipitation of corresponding bulk compounds [19].

In this paper, we report study effects of ammonium solution as a $\mathrm{pH}$ adjuster on chemical bath deposited copper aluminum diselenide thin films on microscope glass substrates by varying the volume $(1-9 \mathrm{~mL})$ of $\mathrm{NH}_{3}$ solution in which optical properties of the films were investigated.

\section{Experimental Methods}

The CuAlSe $e_{2}$ compound thin films were obtained from $\mathrm{CuCl}_{2} \cdot 2 \mathrm{H}_{2} \mathrm{O}$, $\left.\mathrm{Al}_{2}\left(\mathrm{SO}_{4}\right)_{3} .14 \mathrm{H}_{2} \mathrm{O}\right)$, and $\mathrm{Na}_{2} \mathrm{SeSO}_{3}$ as sources of $\mathrm{Cu}^{2+}, \mathrm{Al}^{3+}$ and $\mathrm{Se}^{2-}$, respectively were used as received. All the reagents used were analytical grade. Ethylenediame acetic acid disodium salt (EDTA) was used as a complexing agent during the deposition and ammonia solution acted as source of $\mathrm{pH}$ adjuster. A glass rod was used as a stirrer, mercury in glass thermometer was used to measure the bath temperature and Mac digital $\mathrm{pH}$ meter (MSW-552 model) was used to measure the $\mathrm{pH}$ of the solution. The chemical baths were prepared by putting $5 \mathrm{~mL}$ of 0.1 molar solution of copper chloride, $5 \mathrm{~mL}$ of 0.1 molar solution of $\mathrm{Al}_{2}\left(\mathrm{SO}_{4}\right)_{3} .14 \mathrm{H}_{2} \mathrm{O}, 5 \mathrm{~mL}$ of 0.1 molar solution of EDTA in a growth beaker were prepared and the solution was latter stirred before adding $5 \mathrm{~mL}$ of sodium selenosulphate and $1-9 \mathrm{~mL}$ of ammonia solution respectively and deep bluish coloration was observed. When sodium selenosulphate was added, the solution did not dissolve until it was heated to temperature of $33{ }^{\circ} \mathrm{C}$. Each bath was filled up to $50 \mathrm{~mL}$ mark with distilled water and stirred gently and long enough to ensure uniformity of the mixture. Pre-degreased microscope glass substrates cleaned with distilled water and dried in air were then inserted vertically in the reaction bath while synthetic foam which partly covered the top of the bath. Five different mixtures using $1.0 \mathrm{~mL}, 3.0 \mathrm{~mL}$, $5.0 \mathrm{~mL}, 7.0 \mathrm{~mL}$ and $9.0 \mathrm{~mL}$ of ammonia solution were prepared at room temperature of $33{ }^{\circ} \mathrm{C}$ and left undisturbed for twenty four hours. All the samples were further washed in distilled water and air - dried for analysis. The substrates introduced into the reaction bath gave reaction details as hereunder stated,

$$
\begin{array}{lll}
\mathrm{CuCl}_{2} \cdot 2 \mathrm{H}_{2} \mathrm{O}+\mathrm{EDTA} & \rightarrow & {[\mathrm{Cu}-\mathrm{EDTA}]^{2+}+2 \mathrm{Cl}^{-}+2 \mathrm{H}_{2} \mathrm{O}} \\
{[\mathrm{Cu}-\mathrm{EDTA}]^{2+}} & \rightarrow & \mathrm{Cu}^{2+}+\mathrm{EDTA} \\
\left(\mathrm{Al}_{2}\left(\mathrm{SO}_{4}\right)_{3} \cdot 14 \mathrm{H}_{2} \mathrm{O}\right)+\mathrm{EDTA} & \rightarrow & 2[\mathrm{Al}-\mathrm{EDTA}]^{3+}+3 \mathrm{SO}_{4}^{2-}+14 \mathrm{H}_{2} \mathrm{O} \\
{\left[\mathrm{Al}_{-} \mathrm{EDTA}\right]^{3+}} & \rightarrow & \mathrm{Al}^{3+}+\mathrm{EDTA}^{2-} \\
\mathrm{Na}_{2} \mathrm{SeSO}_{3}+\mathrm{OH}^{-} & \rightarrow & \mathrm{Na}_{2} \mathrm{SO}_{4}+\mathrm{HSe}^{2-} \\
2 \mathrm{HSe}^{2-}+2 \mathrm{OH}^{-} & \rightarrow & 2 \mathrm{H}_{2} \mathrm{O}+2 \mathrm{Se}^{2-} \\
\mathrm{Cu}^{2+}+\mathrm{Al}^{3+}+2 \mathrm{Se}^{2-} & \rightarrow & \mathrm{CuAlSe}_{2}
\end{array}
$$

The optical characterization recorded the optical absorbance carried out with the aid of Jenway6405 UV-Vis spectrophotometer. The instrument gives the extent of absorbance, $\mathrm{A}$, of the optical spectra for the range of $200 \mathrm{~nm}-1100 \mathrm{~nm}$ but wavelength range from $300-700 \mathrm{~nm}$ was used. The film-coated microscope glass substrates were placed across the sample radiation pathway while the uncoated substrate was put across the reference path.

\section{Results and Discussion}

During the growth of $\mathrm{CuAlSe}_{2}$ thin film from chemical bath, EDTA functioned as a complex agent that bound $\mathrm{Cu}^{2+}$ and $\mathrm{Al}^{3+}$ ions since the formation of complexes ions is important to control reaction rate in the solution. Slow hydrolyses of metals occurred and generated $\mathrm{Cu}^{2+}$ and $\mathrm{Al}^{3+}$ in the solution. While $\mathrm{OH}^{-}$from ammonium solution furnishes the necessary $\mathrm{Se}^{2-}$ ions by hydrolysis. Addition of Ammonium solution contributed in $\mathrm{NH}_{3}$ being present in the solution which favors increment in $\mathrm{Se}^{2-}$ release in the solution. In the presence of sufficient EDTA, $\mathrm{Cu}^{2+}$ and $\mathrm{Al}^{3+}$ ions exist in the solution mainly as [Cu - EDTA ${ }^{2+}$ and [Al-EDTA] ${ }^{3+}$. The deposition of $\mathrm{CuAlSe}_{2}$ occurs when the ionic product of $\mathrm{Cu}^{2+}, \mathrm{Al}^{3+}$ and $\mathrm{Se}^{2-}$ exceeds the solubility product. Ammonium solution is added to the 
chemical bath to adjust the $\mathrm{pH}$ from 9 to 11 under the control of a $\mathrm{pH}$ meter. Layer thickness is estimated by the weight method.

The effects of $\mathrm{pH}$ on the films thickness shows that both are inversely related as shown in Fig. 1. This shows that as $\mathrm{pH}$ value increases, decrease in the thickness of the films set in. This could be that as volume (1-9 mL) of ammonium solution increases, deposition of copper aluminium diselenide films is hindered. For thickness measurement, gravimetric weight difference method was used to measure film thickness with the relation $t=\frac{m}{\rho A}$ where, $\mathrm{m}$ is the mass of the film deposition on the substrate in gram; $\mathrm{A}$ is the area of the deposited film in $\mathrm{cm}^{2}$ and $\rho$ the density of the deposited material in bulk form [22]. It is also expected that increase in $\mathrm{pH}$ value led to the decrease in film thickness which could be that the grain size of film decreased [23]

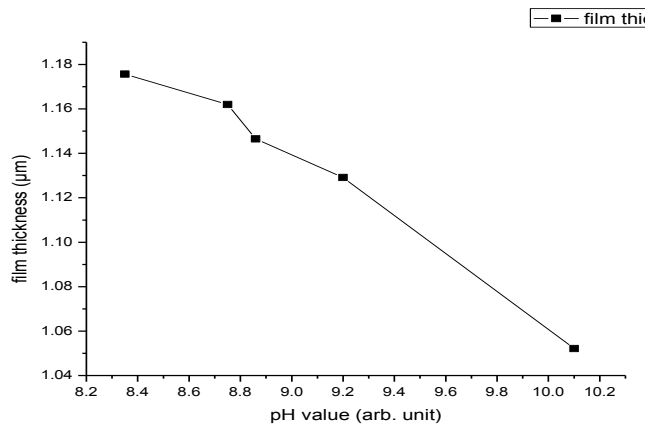

Fig. 1 Plot of film thickness versus pH value

Table 1 Variation of film thickness with deposition $\mathrm{pH}$

\begin{tabular}{lll}
\hline Sample No & Thickness $(\mu \mathrm{m})$ & $\mathrm{pH}$ Value (Arb. Unit) \\
\hline 11 & 1.1757 & 8.35 \\
12 & 1.1620 & 8.75 \\
13 & 1.1465 & 8.86 \\
14 & 1.1291 & 9.20 \\
15 & 1.0521 & 10.10 \\
\hline
\end{tabular}

Fig. 2 shows that increase in $\mathrm{pH}$ value resulted to increase in absorbance of the film. It shows that copper aluminium diselenide have high absorption in the ultraviolet region at ca. $300 \mathrm{~nm}$ than in any other region of the spectrum. This makes the material to be suitable for good absorption of UV radiation. This means that the material can be used as a UV filters. Because of the attributed effects of decrease in grain size, photon absorption increased at wavelength range of 300-380 nm. This stated wavelength range fall in ultraviolet region of electromagnetic spectrum. This shows that these films can be used as shield from ultraviolet which is harmful to humans.

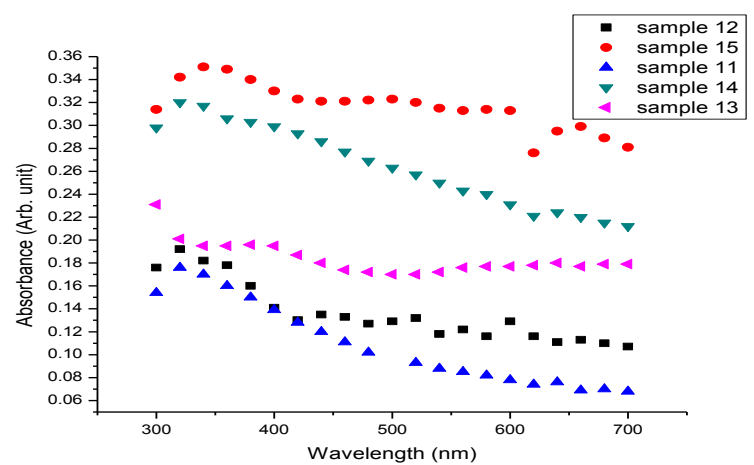

Fig. 2 Plot of absorbance of various $\mathrm{pH}$ values with wavelength

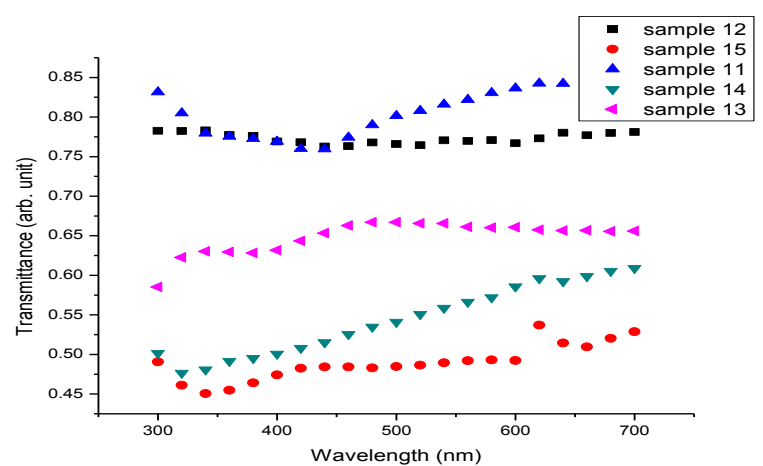

Fig. 3 Plot of transmittance of various pH values with wavelength
Fig. 3 shows the $\mathrm{pH}$ effect value on the transmission spectra in for the range $300-700 \mathrm{~nm}$. It has been found that film transmission increases with decreasing $\mathrm{pH}$ value in solution, which causes decrease of grain size as a result of decreasing the film thickness and consequence transmission increases. The optical transmittance of the film is observed to decrease from ca. $82 \%$ to $45 \%$ with increasing $\mathrm{pH}$ value. Observed wide transmission in the nearly entire visible region $(450-700 \mathrm{~nm})$ enables it to be a potential candidate for optoelectronic application. The transmission in the films increases as the volume of ammonium solution decreases. The decrease in transmittance may be attributed to the decrease in thickness of the films with increasing $\mathrm{pH}$ value. The UV transparencies of all the films were much lower due to electron transitions between the valence band and conduction bands. The substantial decrease in UV transparency could be caused by the scattering from pores and other defects heavily present in the films.

Absorption coefficient of the films, as shown in Fig. 4, increases as the as the volume of ammonium solution increases. This could be attributed to formation of small grains as the volume of $\mathrm{pH}$ adjuster increases. As said in Fig. 3, absorption was maximized at $4.0 \mathrm{eV}$ which lies in the ultraviolet region of the spectrum. The absorption coefficient, $\alpha$, is estimated from $I=$ $I_{0} e^{-\alpha t}$ where $\alpha, I, I_{0}$ and $t$ are absorption coefficient, absorbed beam, incident beam and film thickness.

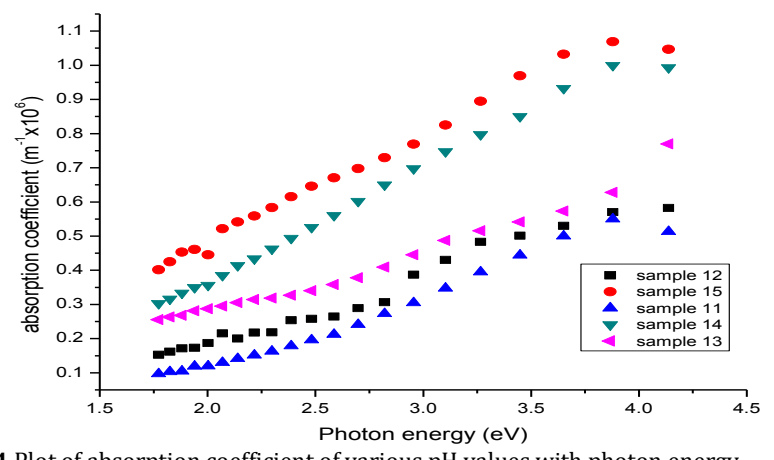

Fig. 4 Plot of absorption coefficient of various $\mathrm{pH}$ values with photon energy

Optical band gap of semiconductor is an important parameter in defining its light absorption behavior. When a photon energy, $h v$, is absorbed, electron-hole pair is generated in the semiconductor which excite electrons resulting in delocalizing it in the conduction band leaving behind delocalized hole in the valence band and results to band - to- band transition [20]. Optical band gap $\left(E_{g}\right)$ of film as shown in Fig. 5 was estimated from transmittance data. The photon energy $(\mathrm{h} v)$ and absorption coefficient $(\alpha)$ for direct optical transition are related by the following equation [24].

$$
\alpha=\frac{A}{h v}\left(h v-E_{g}\right)^{\frac{n}{2}}
$$

where hu is the photon energy, $\alpha$ is the absorption coefficient, Eg is the optical band gap, $\mathrm{A}$ is a constant and $\mathrm{n}=1$ or 4 . The energy band gap could obtain from straight line plot of $(\alpha h v)^{\frac{2}{n}}$ vs. hu by extrapolating of the line to base line. If a straight-line graph is obtained for $n=1$, it is attributed to direct electron transition from valence band to conduction band whereas $\mathrm{n}=4$, there is indirect transition of electrons from valence band to conduction band [25]. For calculation of the optical band gap of CuAlSe film, the curve of $(\alpha \mathrm{hu})^{2}$ vs. hu was plotted. The $\mathrm{E}_{\mathrm{g}}$ value of the CuAlSe $\mathrm{e}_{2}$ film was determined from Fig. 5 and it was found increases from $2.3 \mathrm{eV}$ to 3.0 $\mathrm{eV}$ as $\mathrm{pH}$ values decrease. These energies are slightly higher than earlier reported by [13] this can be attributed to the effect of grain size and the crystal quality was decreases with increasing $\mathrm{pH}$ value in solution

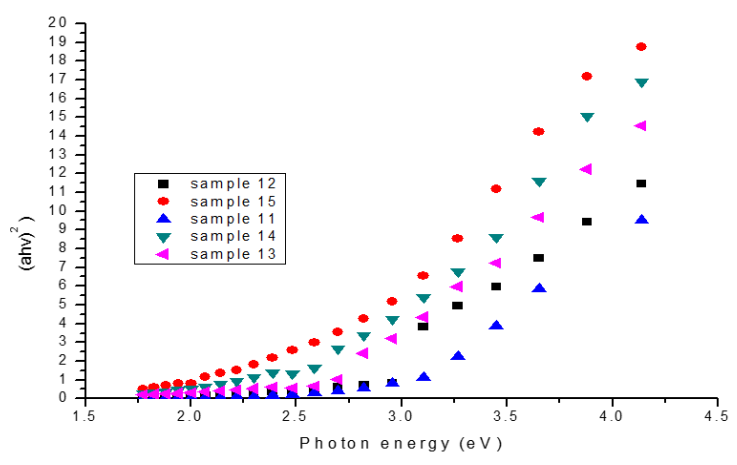

Fig. 5 Plot of $(\mathrm{ahv})^{2}$ of various pH values with photon energy 


\section{Conclusion}

Optical properties of copper aluminium diselenide thin films is studied and this material is good candidate for optoelectronic properties by having moderate transmission in visible region of the spectrum and a good UV filter since it absorbs mainly in ultraviolet region. The effect of ammonium solution on this as deposited material shows that increase in the volume of the $\mathrm{pH}$ adjuster leads to decrease in optical band gap of the material due to decrease in film thickness as the $\mathrm{pH}$ values increase.

\section{References}

[1] S. Shirakata, S. Chichibu, S. Matsumoto, S. Isomura, Photoreflectance study of $\mathrm{CuAlSe}_{2}$ heteroepitaxial layers, Jpn. J. Appl. Phys. 32 (1993) 167-169.

[2] D.C. Perng, T.T. Kao, R.P. Chang, Formation of wide band-gap CuInAlS 2 thin film and its application to UV detectors, Thin Solid Films 572 (2014) 28-32.

[3] Y.B.K. Reddy, V.S. Raja, Preparation and characterization of CuIn ${ }_{03} \mathrm{Al}_{07} \mathrm{Se}_{2}$ thin films for tandem solar cells, Sol. Energy Mater. Sol. Cells 90 (2006) 1656-1665.

[4] J.L. Opez-García, C. Maffiotte, C. Guill_en, Wide-bandgap CuIn1-xAlxSe2 thin films deposited on transparent conducting oxides, Sol. Energy Mater. Sol. Cells 94 (2010) 1263-1269.

[5] L.M. Woods, A. Kalla, D. Gonzalez, R. Ribelin, Wide-bandgap CIAS thin-film photovoltaics with transparent back contacts for next generation single and multi-junction devices, Mater. Sci. Eng. B 116 (2005) 297-302.

[6] T. Nakada, Y. Hirabayashi, T. Tokado, D. Ohmori, T. Mise, Novel device structure for $\mathrm{Cu}(\mathrm{In}, \mathrm{Ga}) \mathrm{Se}_{2}$ thin film solar cells using transparent conducting oxide back and front contacts, Sol. Energy 77 (2004) 739-747.

[7] R. Caballero, S. Siebentritt, K. Sakurai, C.A. Kaufmann, M.C. Lux-Steiner, CGSthin films solar cells on transparent back contact, in: IEEE 4th World Conference on Photovoltaic Energy Conversion, Hilton Waikoloa Village Waikoloa, HI, USA, 2006, pp.479-482.

[8] M. Kul, Electrodeposited SnS film for photovoltaic applications, Vacuum 107 (2014) 213-218.

[9] A. Eifler, E.A. Kudritskaya, I.V. Bodnar, V. Riede, Infrared and Raman study of lattice vibrations of CuAlSe 2 single crystals, J. Phys. Chem. Sol. 64 (2003) 19831987.

[10] S.S. Samanta, M.S. Shinde, D. Salunke, R.S. Patil, Studies on growth and characterization of CdTe thin films deposited by chemical bath deposition technique, Arch. Appl. Sci. Res. 7(11) (2015) 10-15
[11] J. Li, Preparation and properties of CdS thin films deposited by chemical bath deposition, Ceramics Int. 41 (2015) S376-S380.

[12] M.P. Deshpande, N. Garg , S.V. Bhatt, P. Sakariya, S.H. Chaki, Characterization of CdSe thin films deposited by chemical bath solutions containing triethanolamine, Mater. Sci. Semicond. Proces. 16 (2013) 915-922.

[13] J.L. Opez-García, C. Guill_en, Formation of semitransparent CuAlSe 2 thin films grown on transparent conducting oxide substrates by selenization, J. Mater. Sci. 46 (2011) 7603-7610.

[14] J. Singh, D. Prasher, K. Nigam, P. Rajaram, Growth and characterization of pulse electrodeposited CuAlSe $e_{2}$ thin films, in: AIP Conference Proceedings, Bikaner, Rajasthan, India, 2013, pp.473-474.

[15] A. Antony, A.S. Asha, R. Yoosuf, R. Manoj, M.K. Jayaraj, Growth of $\mathrm{CuInS}_{2}$ thin films by sulphurisation of Cu-In alloys, Solar Energy Mater. Solar Cells 81 (2004) 407-417.

[16] S.C. Ezike, D.N. Okoli, Deposition temperature effects on $\mathrm{CuAlSe}_{2}$ compound thin films prepared by chemical bath deposition technique, Int. Org. Sci. Res. Jour. Appl. Phys. 1(3) (2012) 23-26.

[17] A. Kassim, H.S. Min, T.W. Tee, N.C. Fei, Influence of triethanolamine on the chemical bath deposited NiS thin films, Amer. J. Appl. Sci. 8(4) (2011) 359-361.

[18] G.R. Fajinmi, J.S.A. Adelabu, Preparation and characterization of chemically deposited cadmium sulphide thin films, Pacific J. Sci. Technol. 10(3) (2009) 817-822.

[19] I.O. Oladeji, L. Chow, A study of the effects of ammonium salts on chemical bath deposited zinc sulfide thin films, Thin solid films 339 (1999) 148 -153.

[20] T.S. Liang, Z. Zainal, T.W. Tee, I. Hamadneh, Potentiostatic deposition of copper indium disulphide thin films: effect of cathodic potentials on the optical and photoelectrochemical properties, Malay. Jour. Anal. Sci. 12(3) (2008) 600-608.

21] A. Kassim, Z. Kuang A. Sharif, M.J. Haron, W.T. Tee, M. Ho Soon, Effects of deposition potential on $\mathrm{Cu}_{4} \mathrm{SnS}_{4}$ thin films prepared by electrodeposition technique, Arab. Jour. Sci. Engg. 35(1A) (2009) 83-91.

[22] H.H. Ahmed, A.B. Dakhel, The effect of the solution concentration on structural and optical properties CdS thin films prepared by chemical bath deposition technique, Int. J. Recent Res. Rev. 4 (2012) 8-13

[23] H.A. Hani, S.K. Abdullah, S.A. Faris, Effect pH on structural and optical properties of nanostructure CdS films prepared by chemical bath deposition technique, J. Univ. Anbar Pure Sci. 7(1) (2013) 1-8.

[24] M.A. Green, Solar cells: operating principles, technology and system applications, Prentice-hall, Englewood Cliffs, NJ, 1982.

[25] K. Anuar, Z. Zulkarnain, N. Saravanan, A. Zuriyatina, R. Sharin, Preparation and studies of nickel sulfide thin films in the presence of sodium tartate as a complexing agent, Mat. Sci. (Medziagotyra) 10(2) (2004) 157-161. 